Tropical Agricultural Pesearch \& Extension 20 (1 \& 2): 2017

\title{
EFFECT OF NANO-CALCITE FOLIAR FERTILIZER ON GROWTH AND YIELD OF Oryza sativa VARIETY AT 362
}

\author{
KHCH Kumara ${ }^{1}$, RF Hafeel ${ }^{2}$, DL Wathugala ${ }^{3 *}$ and HKMS Kumarasinghe ${ }^{3}$ \\ ${ }^{1}$ Faculty of Graduate Studies, University of Ruhuna, Sri Lanka \\ ${ }^{2}$ Rice Research Station, Ambalantota, Sri Lanka \\ ${ }^{3}$ Department of Crop Science, Faculty of Agriculture, University of Ruhuna, Sri Lanka
}

\begin{abstract}
A pot experiment in an open area was conducted in 2015 yala season at the Regional Rice Research Institute, Ambalantota, Sri Lanka to determine the effect of foliar application of nano calcite on yield, yield component and quality of rice (Oryza sataiva) variety, At 362. Treatments tested were 4 levels of nano calcite $(40,80,120$ and 160 ppm) and plant growth were estimated 30, 60 and 90 days after transplanting and grain yield at harvesting. The experiment followed the Randomized Complete Block Design with 3 replications. It was found that the application of nano calcite foliar fertilizer has significantly contributed to enhance growth, yield, seed quality and insect resistance in At 362. Plants treated with 120 ppm nano calcite had highest yield with highest performances of growth and seed quality attributes. The dates required for the $50 \%$ flowering was reduced by 6 days and yield was increased by $25 \%$ with the application of $120 \mathrm{ppm}$ nano calcite compared to the untreated plants. The plants treated with $160 \mathrm{ppm}$ foliar nano calcite recorded significantly low gall midge damage, leaf mites, stem borer damage and paddy bugs as compared to untreated control and treated with lower doses (40 and 80 ppm). While the data of this study showed that nano calcite has positive effects on rice growth, yield and induced resistance to insect pests, further research would be needed to validate the observations.
\end{abstract}

Key words: Nano calcites, rice, growth, yield, induce resistance to pests

\section{INTRODUCTION}

Along with magnesium and sulfur, calcium is one of the three secondary nutrients essential for crop growth and development. Similar to the major primary nutrients those secondary nutrients are also essential for healthy growth of plants in very small quantities. Calcium plays a very important role in plant growth and nutrition as well as cell wall depositions. The primary roles of calcium within the plants are nutrient transportation into and within the plant, important constituent of cell walls, facilitating metabolic activities by neutralizing cell acids, increasing plant resistance to outside attacks and allowing more erect stems. Calcium deficiency symptoms such as necrosis at the tips and margins of young leaves, bulb and fruit abnormalities, and deformation of affected leaves, highly branched, short, brown root

\footnotetext{
*Corresponding author: wgdlakmini@crop.ruh.ac.lk
}

systems, severe, stunted growth, and general chlorosis, of crops are often identified as physiological disorders.

Plant roots absorb calcium from the soil solution in the form of $\mathrm{Ca}^{2+}$ ions. Although calcium is found in many natural minerals like calcite in soil, calcium disorders are often observed in crop plants. This happens due to various reasons. First, calcium in soil minerals is found in relatively insoluble forms such as calcium carbonate. Second, a low $\mathrm{pH}$ of the soil substrate affects the high concentration of cations such as $\mathrm{Mg}^{+2}, \mathrm{NH}^{4+}, \mathrm{Fe}^{+3}$ and $\mathrm{Al}^{+3}$ decreasing the calcium uptake by plants (Clarkson and Sanderson, 1971; Haynes, 1986). Third, organic acids form chelate complexes with $\mathrm{Ca}^{2+}$ ions which are insoluble (Ochmian I , 2012). 
In modern days foliar fertilization is increasingly adopted to alleviate macro and micro nutrient deficiencies due to various environmental stresses. Beside particular interest has also been gained on nano fertilizers in plant nourishment since they are environmentally safe and benign. Nano particles are tiny materials where dimensions are fall within the nano metric scale. Thus nano materials have high specific surface area, which increase the availability to the plant and grater dissolution of their nutrients in water (Remya et al., 2010).

There are several nano fertilizers available in the market, produced from calcite which is a natural mineral exists in the earth crust. Natural calcite consists of several ingredients such as $\mathrm{CaCO}_{3}, \mathrm{MgO}, \mathrm{K}_{2} \mathrm{O}$ and $\mathrm{Na}_{2} \mathrm{O}$ in various compositions. This natural calcite can be converted into nano size particles by tribo mechanical activation (TMA), which can be used as a foliar nano-fertilizer. This technology does not interfere with the mineral initial composition it only breaks it into nanoparticles with increased reactivity (Prifti and Maci, 2017). This type of nano particles enter into the plant cells through the nano sized stomata opening because the granularity of the nano-calcium carbonate is far smaller than that of the stomata (Kara and Sabir, 2010). Inside the leaf this particles break down into carbon dioxide, and calcium oxide (Chen et al., 2004) which are immediately available for plant. It is a basic physiological phenomenon that higher $\mathrm{CO}_{2}$ concentration inside that plant cells reduce water need of the plant because the atmosphere inside the plant is saturated with $\mathrm{CO}_{2}$ causing the stomata to close. Then evaporation will be limited and water needs for plant will reduce. On the other hand rubisco can easily binds with $\mathrm{CO}_{2}$ and induces photosynthetic activity of the plant. Meanwhile higher $\mathrm{CO}_{2}$ concentrations inside the plant reduce photorespiration which is competitive process with photosynthesis, consume lot of energy and water and reducing the photosynthesis by $20-30 \%$. Also $\mathrm{Ca}(\mathrm{OH})_{2}$ can be produced as a result of $\mathrm{CaO}$ combining with water then which can be caused for proper $\mathrm{pH}$ balancing of the cytoplasm enhancing metabolic activities.

The positive effects of nano calcite have been observed by several researchers for crops like: lettuce (Ugrinović et al., 2011), chop (Weihrauch et al., 2011), potatoes (Trawczyński, 2013; Liu et al., 2005), sugar beet (Artyszak et al., 2014, 2015, 2016a and 2016b), wheat and corn (Prifti and Maci, 2017), grape vine (Kara and Sabir, 2010, Attiar et al., 2014), peanut (Liu et al., 2005) tomato and tankan (Citrus tankan Hayata) (Hua et al., 2015). It has been reported that the spraying nano calcite has increase the total crop biomass, crop productivity, crop growth, vigor, yield, and crop product quality and shorten vegetative period, improve plants ability to resist pests, pathogens and abiotic stresses like drought and salinity, significant increase of the dry matter content in fruits and vegetables, longer storage life, organoleptic qualities colouration and better taste in those crops. Therefore, around the world, nano calcite is being used intensively as an environmentally friendly alternative for synthetic fertilizers. But in Sri Lankan context it has not yet been experimentally analyzed the effect of foliar application of nano-calcite on yield, yield component and quality of rice. Therefore, the main objective of this research was to investigate the effect of foliar application of different concentrations of nano calcite on the growth, yield and quality responses of rice. In addition, the effectiveness of nano calcite in inducing plants resistance to insect pests was also investigated.

\section{MATERIALS AND METHOD}

The experiment was conducted in the Regional Rice Research Station, Ambalanthota (6 ${ }^{0} 130$ 'N and $81^{\circ} .032$ 'S $)$ in the low country (137 $\mathrm{m}$ Mean Sea Level) dry zone (annual rain fall $800-1000 \mathrm{~mm}$ ) of Sri Lanka during June 2015 to September 2016 (yala 2015) situated with reddish brown soil series. Oryza sativa variety At 362 and Herba-Green product, Nano Calcite (http://www.acting-HerbaGreen.com) was used for the experiment. According to the specifica- 
tions of the manufacturer, product is $100 \%$ natural containing $\mathrm{CaCO}_{3}-65.5 \%, \mathrm{SiO}_{2}-17 \%$, $\mathrm{MgCO}_{3}-3.6 \%, \mathrm{Fe}_{2} \mathrm{O}_{3}-3.4 \%, \mathrm{~K}_{2} \mathrm{O}-0.7 \%, \mathrm{Na}_{2} \mathrm{O}$ $-0.5 \%$ S- $0.4 \%, \mathrm{P}_{2} \mathrm{O}_{5}-0.2 \%$ and $\mathrm{MnO}-0.1 \%$. Nano calcium carbonate level of the product according to the purity is $82.3 \%$. Fourteen day old rice seedlings were established in pots (531.19 $\mathrm{cm}^{2}$ surface area) filled with paddy field soil. Four seedlings were established per pot with $15 \mathrm{~cm}$ spacing (fig 1). Four concentration of nano calcite $(40,80,120,160 \mathrm{ppm})$ was used for the experiment. All concentrations were prepared using tap water. Water alone was used as the control. Each concentration was sprayed 20, 40 and 60 days after transplanting (DAT). Each pot was sprayed with $10 \mathrm{ml}$ of nano calcite 20 DAT (therefore, the application rate of nano calcite for 40,80 , 120 and $160 \mathrm{ppm}$ concentrations were 0.1 , $0.2,0.3$ and $0.4 \mathrm{mg} /$ plant, respectively). The application volume was increased to $40 \mathrm{ml}$ in $2^{\text {nd }}(40$ DAT $)$ and $3^{\text {rd }}(60$ DAT $)$ sprays (therefore the application rate of nano calcite for $40,80,120$ and $160 \mathrm{ppm}$ concentrations were $0.4,0.8,1.2$ and $1.6 \mathrm{mg} / \mathrm{plant}$ respectively). Applications were performed with a hand-pump pressure spray systems. Soil fertilizer was added according to the recommendations of Department of Agriculture, Sri Lanka. Where triple super phosphate $(55 \mathrm{~kg} /$ ha) was applied as the basal dressing and 50 , 75,65 and $35 \mathrm{~kg} /$ ha urea was added in 2,4,6 and 7 weeks after planting respectively. $\mathrm{Mu}-$ rate of potash was added in $4^{\text {th }}$ and $6^{\text {th }}$ week after planting at the rate of 25 and $35 \mathrm{~kg} / \mathrm{ha}$.

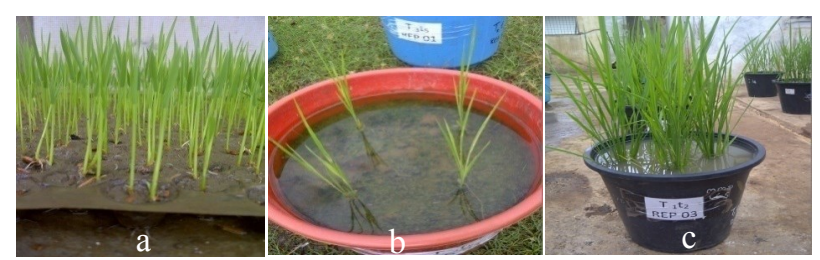

Figure 1: Several stages of the experiment. a) Seedling nursery; b) Experimental unit just after seedling establishment; c) appearance of the experimental unit 30 days after transplanting
All other management practices including watering were identical for all treatments. Rice plant growth and yield parameters, induced resistance to insect pests and grain quality parameters were taken 30, 60 and 90 days after transplanting and at the harvesting. Randomly selected three plants from each replicate were used for data collection. The experiment followed the Randomized Complete Block Design with 3 replications. In order to analyze significant differences, one factor analysis of variance with the level of significance $\alpha=0.05$ was carried out. Duncan's multiple range tests were performed for multiple pair wise differences across treatments.

\section{RESULTS AND DISCUSSION}

Several studies observed that the application of nano calcite as a foliar fertilizer can improve growth and development of crops and increase ultimate crop yield under similar agronomic practices. Further improved plant resistance to biotic and abiotic stresses has also been reported by several authors with the application of foliar calcium fertilizers.

In this study, nano calcite treatments have significantly effected on growth of paddy variety At 362. Significant variation of plant height (clump height) could be observed with the increase of nano calcite concentration up to 120 ppm (Figure 2). Not only for plant height, nano calcite level $120 \mathrm{ppm}$ gave the highest performances for all parameters collected in 30, 60 and 90 days after transplanting. Statistically significant difference was not observed in leaf area/plant, number of insect pests/plant and SPAD readings of chlorophyll content for different nano calcite levels at 30 days after transplanting. However, significant differences were observed in 60 and 90 days, after transplanting for these three parameters as well. Sabir et al. (2014) also reported significant increase of leaf chlorophyll content with nano calcite treatments of "Narince" grape cultivated on alkali soil. Further Chithrani et al. (2015) observed significant differences for total chlorophyll content, fodder yield and sol- 
uble carbohydrate content of sorghum. These findings also revealed that the nano calcite reproductive growth of the rice.

The time taken for $50 \%$ flowering was slightly triggered by nano calcite. Treated plants showed 2-6 days early flowering than those of untreated plants. Such effect of nano calcite was also reported before for Graphs by Sabir et al. (2014).

Significantly highest yield was observed in $120 \mathrm{ppm}$ nano calcite treatment (table 1). All other concentrations were also achieved significantly higher yield compare to the untreated plants. According to the product specifications, calcite foliar fertilizer can be immediately taken up by the plant, and decompose
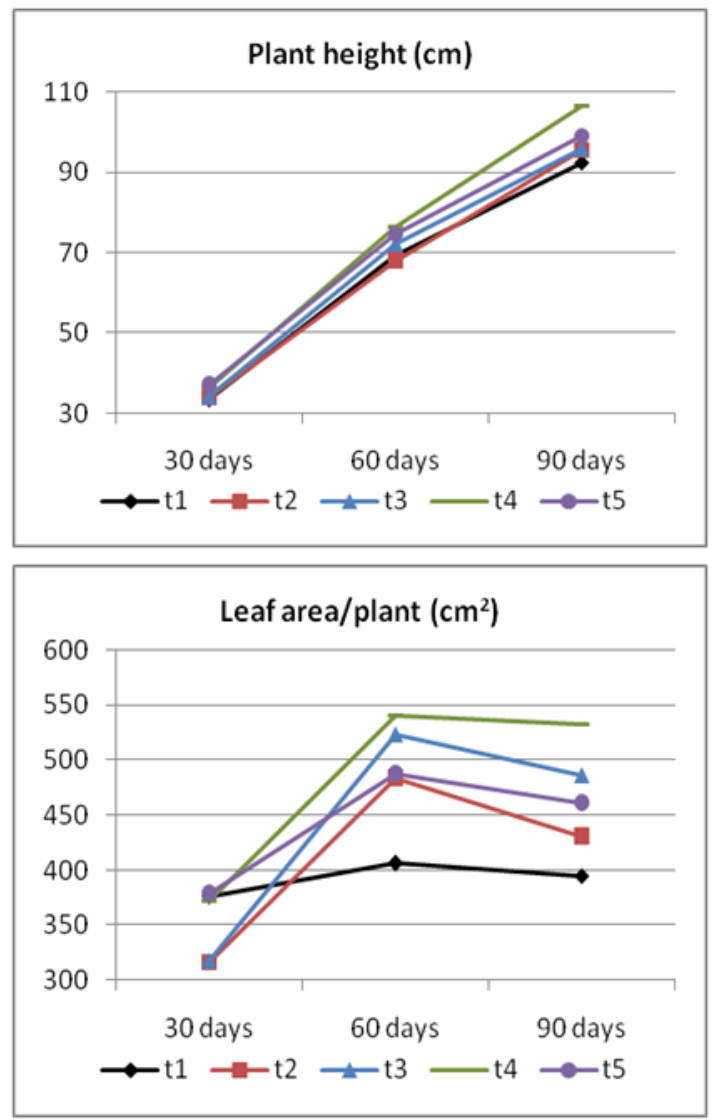
foliar fertilizer increased the vegetative and

into calcium oxide $(\mathrm{CaO})$ and carbon dioxide $\left(\mathrm{CO}_{2}\right)$. Hence available $\mathrm{CO}_{2}$ for photosynthesis increase significantly (Chithrani et al., 2015). Increased chlorophyll content could also have facilitated the higher photosynthetic rate. Therefore, it is obvious that the application of foliar nano-calcite positively influence the final yield. Similarly, Artyszak et al. (2014) observed higher, root, leaves, biological and technological yield of sugar in beet (var. Danuśka KWS) and Chithrani et al. 2015 received higher amount of fodder yield with the application of marine calcite.

Effect of the treatments on grain characters was significantly different among treatments. The 1,000 grain weight, grain length, grain width have increased significantly with increasing nano calcite concentrations. All nano
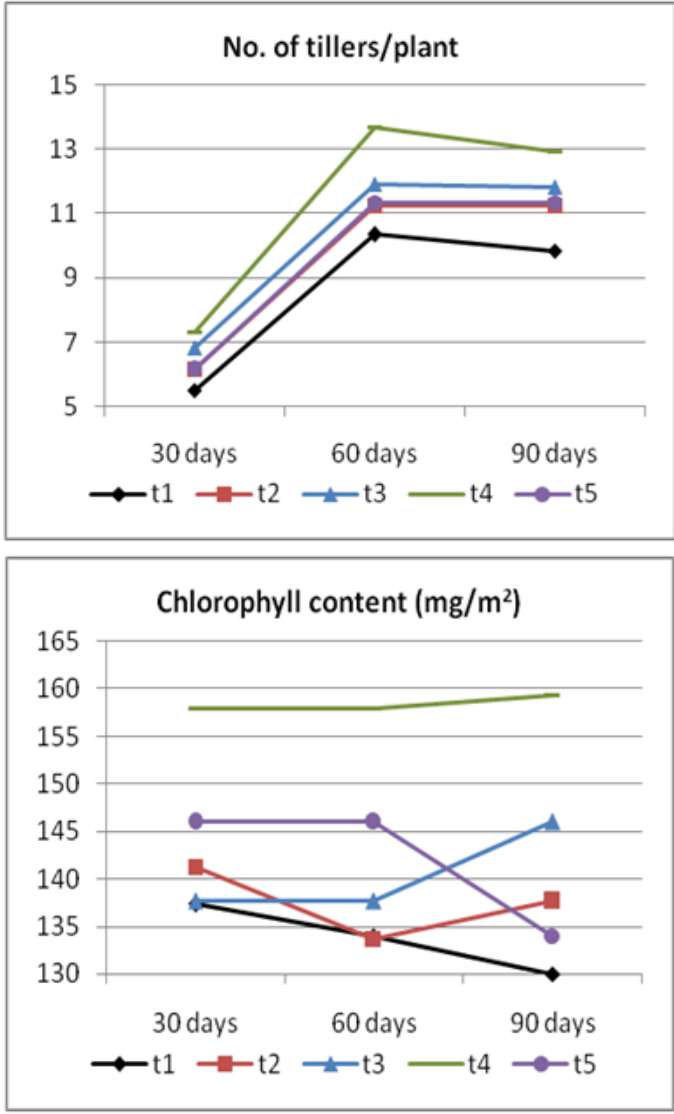

Figure 2: Variation of plant height, number of tillers/plant, number of leaves/plant, leaf area/ plant, number of insect/plant and chlorophyll content with the time after application of nano calcite. Each data point represents the mean of data points obtained from three replicates. Treatments t1 to t5 indicates $0,40,80,120,160 \mathrm{ppm}$ nano calcite application. 
calcite treatments led to increment of grain quality parameters measured in the study. Nonetheless the highest values of grain quality parameters were obtained from $120 \mathrm{ppm}$ nano calcite treatment. Sabir et al. (2014) and Bonomelli and Ruiz (2010) also observed the enhanced berry length of grape vine with the application of nano calcite fertilizers. In an- other study, large fruit sizes of apples (Lanauskas et al., 2012) and increase of seed yield (Sawan et al., 1997) were observed with the application of foliar calcium fertilizer. All these observations indicate that calcium fertilizer can enhance the appearance of rice grains.

Hua et al. (2015) observed 13 times more cal-

Table 1: Effect of different concentrations of nano calcite on the growth and yield performances of At 362rice variety

\begin{tabular}{llllll}
\hline \multicolumn{6}{c}{ Nano calcite concentration $(\mathrm{ppm})$} \\
\hline & 0 & 40 & 80 & 120 & 160 \\
\hline Flag leaf area $\left(\mathrm{cm}^{2}\right)$ & $157.1^{\mathrm{c}}$ & $197.9^{\mathrm{bc}}$ & $239.9^{\mathrm{ab}}$ & $280.6^{\mathrm{a}}$ & $294.6^{\mathrm{a}}$ \\
No. of panicles/ plant & $7.08^{\mathrm{b}}$ & $8.00^{\mathrm{ab}}$ & $8.08^{\mathrm{ab}}$ & $8.50^{\mathrm{ab}}$ & $9.33^{\mathrm{a}}$ \\
No. of seeds / panicle & $76.83^{\mathrm{a}}$ & $102.92^{\mathrm{a}}$ & $107.67^{\mathrm{a}}$ & $109.25^{\mathrm{a}}$ & $96.33^{\mathrm{a}}$ \\
Panicle length (cm) & $17.75^{\mathrm{b}}$ & $21.71^{\mathrm{a}}$ & $22.21^{\mathrm{a}}$ & $18.21^{\mathrm{b}}$ & $18.54^{\mathrm{b}}$ \\
Total plant dry weight (g) & $23.92^{\mathrm{b}}$ & $26.51^{\mathrm{ab}}$ & $27.83^{\mathrm{ab}}$ & $30.23^{\mathrm{a}}$ & $24.53^{\mathrm{b}}$ \\
Grain yield/pot (g) & $87.89^{\mathrm{c}}$ & $90.72^{\mathrm{bc}}$ & $97.42^{\mathrm{b}}$ & $110.54^{\mathrm{a}}$ & $97.54^{\mathrm{b}}$ \\
\hline
\end{tabular}

Means followed by different letters in each row are significantly different at $\mathrm{p} \leq 0.05$ DMRT.

Table 2: Grain characteristics of rice variety At 362treated with the indicated doses of nano calcite.

\begin{tabular}{llllll}
\hline & \multicolumn{6}{l}{ Nano calcite concentration (ppm) } \\
\hline & 0 & 40 & 80 & 120 & 160 \\
\hline 1,000 grain weight (g) & $22.2^{\mathrm{b}}$ & $22.7^{\mathrm{b}}$ & $23.4^{\mathrm{ab}}$ & $25.2^{\mathrm{a}}$ & $23.4^{\mathrm{ab}}$ \\
Grain length with husk (mm) & $7.26^{\mathrm{b}}$ & $7.60^{\mathrm{b}}$ & $8.50^{\mathrm{a}}$ & $8.50^{\mathrm{a}}$ & $8.80^{\mathrm{a}}$ \\
Grain length without husk (mm) & $5.91^{\mathrm{c}}$ & $6.03^{\mathrm{c}}$ & $6.26^{\mathrm{b}}$ & $6.53^{\mathrm{a}}$ & $6.58^{\mathrm{a}}$ \\
Grain width with husk (mm) & $1.73^{\mathrm{a}}$ & $1.78^{\mathrm{a}}$ & $1.85^{\mathrm{a}}$ & $1.96^{\mathrm{a}}$ & $1.81^{\mathrm{a}}$ \\
Grain width without husk (mm) & $1.61^{\mathrm{b}}$ & $1.66^{\mathrm{ab}}$ & $1.69^{\mathrm{ab}}$ & $1.73^{\mathrm{a}}$ & $1.75^{\mathrm{a}}$ \\
\hline
\end{tabular}

Means followed by different letters in each row are significantly different at $\mathrm{p} \leq 0.05$ DMRT.

Table 3: Effect of different concentrations of nano calcite on presence of insect pests and their damage. Data present in the table are average values of three replicates

\begin{tabular}{llllll}
\hline & \multicolumn{5}{l}{ Nano calcite concentration (ppm) } \\
\hline & 0 & 40 & 80 & 120 & 160 \\
\hline $\begin{array}{l}\text { Leaf mite count/cm }{ }^{2} \\
\text { Gall midge damage count (Number of }\end{array}$ & $8.56^{\mathrm{a}}$ & $6.67^{\mathrm{b}}$ & $5.22^{\mathrm{b}}$ & $3.33^{\mathrm{c}}$ & $1.22^{\mathrm{d}}$ \\
galls/ pot) & $4.33^{\mathrm{a}}$ & $3.22^{\mathrm{ab}}$ & $2.44^{\mathrm{b}}$ & $2.00^{\mathrm{b}}$ & $1.11^{\mathrm{b}}$ \\
Yellow stem borer damage/ pot & $2.67^{\mathrm{a}}$ & $1.89^{\mathrm{b}}$ & $1.78^{\mathrm{b}}$ & $0.56^{\mathrm{c}}$ & $0.33^{\mathrm{c}}$ \\
\hline
\end{tabular}

Means followed by different letters in each row are significantly different at $\mathrm{p} \leq 0.05$ DMRT. 
cium and enhanced levels of other macro and micro level nutrients in leaves of tankan (Citrus tankan) treated with nano calcium carbonate. Liu et al. (2005) who studied on peanut also reported greater nutrient acquisition after application of foliar nano calcite. Tantawy et al. (2014) reported that the calcium in the nano forms was superior in its effects compared to the cheated forms, where they have used nano calcium carbonate produced from dolomite and chelated calcium.

Insect damages such as paddy bug, leaf mite, yellow stem borer, gall midge were significantly reduced with the increase of nano calcite concentrations. Comparatively lowest pest attacks were observed in $160 \mathrm{ppm}$ level (table 3). Several studies have been proved that calcium can strengthen plant against pest and diseases which is called as induced resistance. Jarrell and Beverly (1981) showed that calcium can reduce gray mold symptoms and the severity of post harvest Botrytis blight in rose flowers. Hua et al. (2015) have also reported that the application of nano calcium carbonate can increase plant protection against insect pests. They have also mentioned that nano calcium carbonate is a good alternative for chemical pesticides as it is a safe, human and environmentally friendly material.

Nano Calcite foliar fertilizer consists micro nutrients including $\mathrm{Ca}, \mathrm{Fe}, \mathrm{Si}, \mathrm{Mg}, \mathrm{Mn}, \mathrm{Na}$ and $\mathrm{S}$. These micro nutrients also play essential roles in plant physiology. For example, Fe is a co-factor for approximately 140 enzymes that catalyze unique biochemical reactions. Therefore, Fe fills many essential roles in plant growth and development, including chlorophyll synthesis, thylakoid synthesis and chloroplast development (Miller et al., 1995).

Silicon fertilizer application is also a widely used practiced in the world to increase crop production. The favourable effects of $\mathrm{Si}$ on many plant species growth and development were found by some researchers (Hou et al.,
2006; Yamaji et al., 2008). The main role that Si plays is reduction of impacts on plants from abiotic and biotic stresses such as drought, disease, and insect stresses (Gunes et al., 2007; Sacała, 2009). In studies of Tripathi et al. (2012) silicon fertilization of the rice resulted in the increase of the fresh weight of the seedlings' aboveground parts and seedlings' roots compared to control (without silicon fertilization). The authors also reported higher dry matter of rice plants and average height of seedlings. Crusciol et al. (2009) observed significant increase in dry weight of potato tubers after application of silicon fertilization. Therefore, not only harmonizing of photosynthetic process by $\mathrm{CaO}$, other micro nutrients may also contributed to the positive effects on rice growth, yield, quality and insect resistivity achieved in the present study.

\section{CONCLUSION}

The foliar-fertilizer, nano-calcite, is a novel approach to minimize water stress in plants and improve yield. A preliminary study conducted in Sri Lanka to determine its applicability in rice revealed that application of 120 ppm solution of nano-calicte has increased the growth, grain characters (1,000 grain weight, grain length and width), minimized damage caused by mites, gall midge and yellow stem borer.

However, further long term research under different environmental and soil conditions with different varieties and concentrations would be needed to fully understand the effect. Therefore, this research is continuing under field conditions for further elaborate the effect of nano calcite on growth and yield of rice.

\section{REFERENCES}

Artyszak A, Gozdowski D, Kucińska K 2014 The effect of foliar fertilization with marine calcite in sugar beet . Plant Soil Environ . 60: 413417 .

Artyszak A, Gozdowski D, Kucińska K 2015 The effect of silicon foliar fertilization in sugar 
beet - Beta vulgaris (L.) ssp. vulgarisconv . crassa (Alef.) prov. altissima (Döll). Turk. J. Field Crops 20: 115-119.

Artyszak A, Gozdowski D, Kucińska K 2016a Sugar beet morphological traits after foliar application with marine calcite. Farm. Agron. 33(3): 7-17 .

Artyszak A, Gozdowski D, Kucińska K 2016b The effect of calcium and silicon foliar fertilization in sugar beet. Sugar Tech . 18: 109114 .

Bonomelli C, Ruiz R 2010 Effects of foliar and soil calcium application on yield and quality of table grape cv. 'Thompson Seedless'. J. Plant Nutr. 33, 299-314.

Chen LS, Smith BR, Cheng LL $2004 \mathrm{CO}_{2}$ assimilation, photosynthetic enzymes, and carbohydrates of 'Concord' grape leave in response to iron supply. J. Am. Soc. Hort. Sci. 129, 738744.

Chithrani K, Premalal GGC and Wickramasinghe HKJP 2015 Effect of 'Calcite Foliar Fertilizer' on Growth, Yield and Nutritional Composition of Sorghum (Sorghum bicolor L. Moench) Cultivated under Field Condition as a Fodder for Dairy Cattle. Proceedings of 14th Agricultural Research Symposium (2015) 302-306

Gunes A, Inal A, Bagci EG, Pilbeam DJ 2007 Silicon-medi-ated changes of some physiological and enzymatic parameters symptomatic for oxidative stress in spinach and tomato grown in sodic-B toxic soil. Plant and Soil, 290: 103-114.

Hou LQ, Szwonek E, Xing SJ 2006 Advances in silicon research of horticultural crops. Vegetable Crops Research Bulletin, 64: 5-17.

Hua KH, Wang HC, Chung RS and Hsu JC 2015 Calcium carbonate nanoparticles can enhance plant nutrition and insect pest tolerance. J. Pestic. Sci. 40(4): 208-213.

Jarrell WM, Beverly RB 1981 The dilution effect in plant nutrition studies. AdvAgron 34:197224.

Kara Z, Sabir A, 2010 Effects of HerbaGreen application on vegetative developments of some grapevine rootstocks during nursery propagation in glasshouse. In: 2nd International Symposium on Sustainable Development, pp.127132.

Liu X, Zhang F, Zang S, HE X, Wang R., Feng Z, Wang Y 2005 Responses of peanut to nano- calcium carbonate. Plant Nutr. Fert. Sci. 11, 385-389.

Miller GW, Huang IJ, Welkie GW, Pushmik JC 1995 Function of iron in plantswith special emphasis on chloroplasts and photosynthetic activity. In: Abadia, J. (Ed.), Iron nutrition in soils and Plants. Kluwer Academic Publishers, Dordrecht, pp. 1928.

Ochmian I 2012 The Impact of Foliar Application of Calcium Fertilizers on the Quality of Highbush Blueberry Fruits Belonging to the 'Duke' Cultivar. Not Bot Horti Agrobo, 40(2): 163-169

Prifti D and Maci A 2017 Effect of Herbagreen Nano-Particles on Biochemical and Technological Parameters of Cereals (Wheat and Corn) European Scientific Journal February 2017 edition. 13(6) ISSN: 1857 $-7881$.

Remya N, Saino HV, Baiju G, Maekawa T, Yoshida Y, Sakthi Kumar D, 2010 Nano particulate material delivery to plant. Plant Sci. 179, 154-163.

Sabir A, Yazar K, Sabir F, Kara Z, Yazici MA, Goksu N 2014 Vine growth, yield, berry quality attributes and leaf nutrient contentof grapevines as influenced by seaweed extract (Ascophyllum nodosum) and nano size fertilizer pulverizations. ScientiaHorticulturae 175 (2014) 1-8.

Sacała E 2009 Role of silicon in plant resistance to water stress. Journal of Elementology, 14: 619-630.

Trawczyński C 2013 The effect of foliar fertilization of preparation Herba Green on potato yield. Ziemniak Polski 2: 29-33 (in Polish).

Ugrinović M, Oljača S, Brdar-Jokanović M, Zdravković J, Girek Z, Zdravković M 2011 The effect of liquid and soluble fertilizers on lettuce yield. Contemporary Agriculture - The Serbian Journal of Agricultural Sciences, 60: 110-115.

Weihrauch F, Schwarz J, Sterler A 2011 Downy mildew control in organic hops: how much copper is actually needed? Proceed . of the Scientific Commission CIH-IHBIHGC . 19-23 June 2010, Lublin - Poland: $75-78$.

Yamaji N, Mitatni N, Ma JF 2008 A transporter regulating sili-con distribution in rice shoots. The Plant Cell, 20: 1381-1389. 